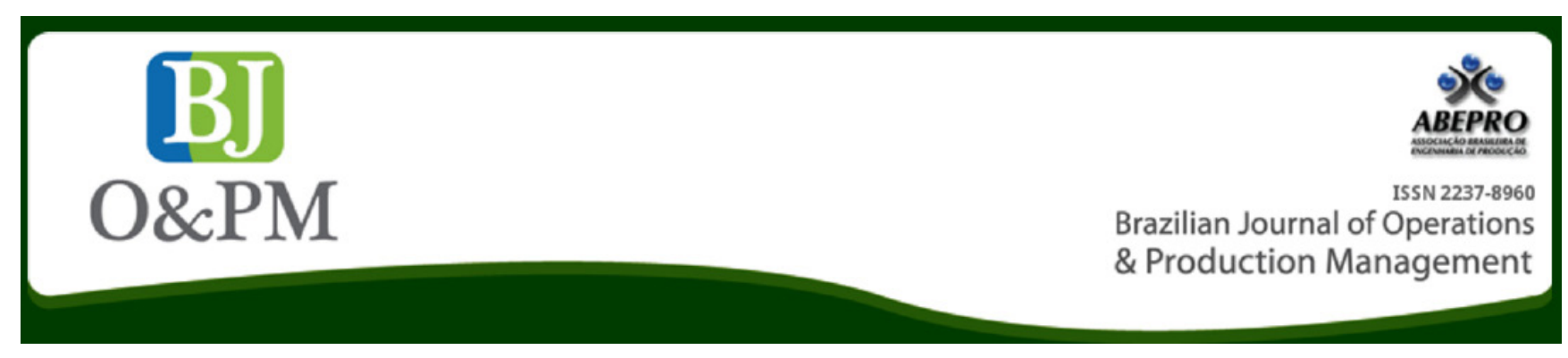

\title{
IMPACT OF MODAL CHOICE IN ENERGY CONSUMPTION AND CARBON DIOXIDE EMISSIONS: ANALYSIS OF BRAZILIAN BIOETHANOL SUPPLY CHAIN
}

\author{
Juliana Monteiro Lopes ${ }^{\mathrm{a}}$; Ilton Curty Leal Juniora; Vanessa de Almeida Guimarães ${ }^{\mathrm{a}}$ \\ ${ }^{a}$ Fluminense Federal University (UFF) - Niterói, RJ, Brasil
}

\begin{abstract}
Purpose - This paper presents a comparative study of scenarios considering different features of the bioethanol supply chain, focusing on the impact of the modal choice and the use of renewable energy on its environmental performance. Currently, the concern with sustainable development leads organizations to improve their production processes in order to reduce greenhouse gas emissions and energy consumption. Therefore, since the bioethanol supply chain is a greater $\mathrm{CO} 2$ emitter and depends on several energy sources, it becomes relevant to analyze how to improve this chain regarding environmental issues.
\end{abstract}

Design/methodology/approach - Based on bibliographic and documental research, this paper analyzes the bioethanol supply chain from the sugarcane plantation, in the South Central region of Brazil, to bioethanol exportation (São Sebastião port). The analysis was based on LCA (life cycle analysis) concepts and in a partial application of LCI (life cycle inventory). It was possible to identify which scenario would be the most appropriate considering the total energy consumption, the percentage of renewable energy used and $\mathrm{CO} 2$ emissions.

Findings - We found that the most appropriate alternative is not the one that uses less energy (roadway combined with pipeline), but the one that uses more renewable energy (roadway using biodiesel). Based on the findings, we concluded that it is possible to improve the environmental performance of the bioethanol supply chain with a combination of renewable energy sources and the selection of modes of transport considered more suitable to this product.

Research limitations/implications - In this study, the economic impacts related to the implementation of the two best alternatives were not evaluated (e.g. the amount of investments required to provide biodiesel as the main energy source and to create or expand the infrastructure for pipelines). Another limitation is the scarce availability of data related to supply chain of bioethanol in Brazil.

Practical implications - This paper provides information to support the public policies for bioethanol's transport and the public and private managers in the decision-making process.

Originality/value - Although there are a lot of studies about the bioethanol supply chain in Brazil, it was not found researches that analyze the impact of modal choice in energy consumption and carbon dioxide emissions considering, at the same time, the life cycle inventory for each transport alternative and different energy sources.

Keywords: Life Cycle Analysis; Life Cycle Inventory; Supply Chain; Bioethanol; Transport Modes 


\section{INTRODUCTION}

Brazil is a major producer of bioethanol in the world (UNICA, 2011). This country has been using this renewable biofuel in transport since the 1970s. In 2008/2009 Brazil produced 27,512,962,000 liters of ethanol, 9,336,343 liters of anhydrous ethanol and 18,176,619 of hydrous ethanol and it is preparing itself to become one of the main exporters of biofuel (UNICA, 2011).

Compared to the life cycle of Brazilian gasoline, the bioethanol supply chain and its final use consume $36 \%$ more energy. Although it uses $93 \%$ of renewable energy which reduces $\mathrm{CO}_{2}$ net emissions and can be considered an advantage of the use of bioethanol (D'Agosto; Ribeiro, 2009).

Making the bioethanol supply chain even less dependent on non-renewable fuels is a challenge that can bring economic advantage and competitiveness to Brazil as an exporter of bioethanol. It involves the identification and selection of alternatives to transferring and distributing the product considering a greater use of renewable energy or modes of transport that are more energy efficient. Transferring and distributing are responsible for the largest consumption of fossil fuels in the ethanol supply chain (D’Agosto; Ribeiro, 2009).

This paper aims to compare different settings of bioethanol supply chains which are composed of modal alternatives and renewable energy sources. The comparison was made through the application of the supply chain inventory $(\mathrm{SCl})$ procedure as a partial implementation of the life cycle assessment procedure (LCA) proposed by D'Agosto et Ribeiro (2012). So it was possible to identify which alternative offers lower total energy consumption, larger renewable energy usage and lower $\mathrm{CO}_{2}$ emission.

From this introduction on, this paper is divided into four sections. Section 2 presents the supply chain of ethanol in Brazil. Section 3 shows the methodological procedures applied in this paper and section 4 contains the development of this study. Finally, in section 5 we present our final considerations.

\section{BIOETHANOL'S SUPPLY CHAIN}

Bioethanol is the renewable alternative fuel most used worldwide and it is known as an automotive fuel since the beginning of 20th century (Mendonça et Leal Junior 2010). In Brazil, the sugarcane is used to produce two types of bioethanol: (1) chloride, which is added at a proportion of $25 \%$ to gasoline and (2) hydrated, mainly used in flex-fuel vehicles, which were $78.4 \%$ of the new vehicles licensed in 2011 (ANFAVEA, 2012).

The sugarcane bioethanol supply chain can be divided into: (1) raw material production; (2) bioethanol production;
(3) bioethanol distribution and (4) final use (D'Agosto; Ribeiro, 2009).

Among Brazilian sugarcane producing regions, we highlight the northeastern region (8.7\% of production) and the south central region (91.3\% of production), which includes São Paulo's countryside, the northwest of Paraná (the largest producer) and the states of Mato Grosso do Sul, Mato Grosso, Minas Gerais and Goiás. São Paulo concentrates more than half of Brazilian ethanol production: $16,722,478,000$ liters from a total of 27,512,962,000 liters in 2008 / 2009 (UNICA 2011). In Brazil it is possible to produce, in average, 85 liters of bioethanol per ton of sugarcane and 74 tons of sugarcane per hectare, which leads to 6290 liters of bioethanol per planted hectare (BNDES, 2007).

In Brazil, ethanol distribution can use an intermodal network, which includes transporting to storage terminals by high capacity transport modes, such as pipelines, and distribution to points of sale by the road mode (Leal Junior; D'Agosto, 2011). In practice, $70 \%$ of the Brazilian bioethanol is being transported by road and only $6 \%$ by pipelines (Dantas Filho et al.,2008; Mendonça; Leal Junior, 2010). Only in northern Brazil is the waterway mode used, with low-volume loads. According to Dantas Filho (2008), in São Paulo, the modal split for 2005 was: $7 \%$ by railways, $0.8 \%$ by pipelines and $92.2 \%$ on highways (Mendonça; Leal Junior, 2010)

Transport uses conventional and alternative energy sources. The conventional energy sources acknowledged worldwide for road transport are gasoline and diesel, both derived from petroleum. The alternative sources available in Brazil are bioethanol, biodiesel and natural gas (D'Agosto; Ribeiro, 2009).

Biofuels are derived from renewable biomass that can replace, partially or totally, fuels derived from oil and natural gas. These biofuels have been used in Brazil since 80 s. However, it was in the 1970s, after the first oil crisis, that its production and use has largely spread (Brasil, 2012). As a fuel for diesel engines, which are used exclusively in agricultural machinery, locomotives and trucks, the main biofuel option to replace petroleum diesel is biodiesel (methyl esters of fatty acid) produced from soybean oil (D'Agosto; Ribeiro, 2009). Compared to petroleum diesel, biodiesel reduces by $78 \%$ the net $\mathrm{CO}_{2}$ emissions per liter of fuel (Leal Junior \& D'Agosto, 2011). In Brazil, since January 1st, 2010, the use of, at least, a B5 blend became mandatory ( $5 \%$ biodiesel and $95 \%$ petroleum diesel) in the whole national territory.

Besides the benefits related to the use of biofuels, we can notice that some actions related to energy use by mode of transport can be taken in order to reach environmental improvements. According to Leal Jr et D'Agosto (2011), the pipeline mode consumes only $6.70 \%$ of the energy consumed by the road mode to perform the same transportation work, 
being one of the most efficient ways to transport fuels, followed by waterways and railways modes. It is noteworthy that in the Brazilian case, the source of energy for the pipelines is hydroelectric, being a $100 \%$ renewable source. The other modes can use as sources both petroleum fuels and renewable fuels, such as B100 (pure biodiesel).

\section{METHODOLOGICAL PROCEDURES}

Life cycle is understood as the successive and chained stages of a production system (of product or service), from raw material acquisition (or extraction) to final disposal. A Life Cycle Analysis (LCA) is a technique for assessing the environmental aspects and potential impacts associated with the stages of a product (Brazilian Association of Technical Standards, 2001).

LCA can have different purposes such as: (1) aiding in decision making process; (2) determining environmental performance indicators for the evaluation and (3) improving the understanding of environmental aspects linked to production processes in a broader way. Thus, it can provide subsidies to change traditional philosophy of environmental protection, which considers the correction of environmental impacts only after its occurrence and not its prevention (D’Agosto; Ribeiro, 2009).

The LCA comprises four phases: objective and scope, inventory analysis, impact assessment and interpretation. D'Agosto et Ribeiro (2009) conducted bibliographic research that indicates that, when it comes to the use of energy for transport, it is common the partial application of LCA, considering only the first two phases (objective and scope, and inventory analysis). This is called Life Cycle Inventory $(\mathrm{LCl})$.

There are many references that apply LCA to energy usage in the transport sector (Armstrong; Akhurst, 2000; Beer et al.,2001; Bouwman; Moll, 2002; Chang; Kendall, 2011; Collela et al.,2005; Demir et al.,2011; Foley et al.,2010; Furuholt, 1995; Ha et al.,2011; Hackney; Neufville, 2001; Hu et al, 2004; IEA, 1999; Kadam, 2002; Kim et al, 2010; Kreith, 2002; Lechon et al.,2009; Lee et al.,2010; Neupane et al.,2011; O'Donell et al.,2009, Ou et al.,2012; Poeschl et al.,2012, Pootakham; Kumar, 2010, Sheehan et al.,1998; Vihermaa et al.,2006, Wang et al.,2005; Wang et al.,1997). However, studies were not found that evaluate the reduction of total energy consumption, the increase in the use of renewable energy and the reduction in $\mathrm{CO}_{2}$ emissions by choosing settings supply chains. Besides, these studies do not considerate the usage of modal alternatives more energy efficient or the use of renewable energy (such as biodiesel and electricity).

D'Agosto et Ribeiro (2009) present a procedure (LCI) divided into four stages specifically developed for the comparison of energy sources for transport: (1) objective and scope; (2) inventory analysis; (3) data evaluation and (4) comparison of the results. The first two stages are part of the LCl. The third and fourth stages are complementary to the inventory. The first stage is divided in two steps: (1) Extension (geographic, temporal and technological) and (2) dimensions.

The life cycle is composed of 5 mid-stages: raw material production, raw material transport, energy-source production, energy-source distribution, and end use. This work has carried out partial implementation of the $\mathrm{LCl}$, excluding the final use of bioethanol and focusing on the supply chain inventory $(\mathrm{SCl})$ that covers the production of raw material, transport of raw materials, energy source production and energy source transport from the producing region to the port for export, considering the use of alternative energy sources in transport and combinations of different modes based on Leal Jr et D'Agosto (2011).

\section{BIOETHANOL LIFE CYCLE INVENTORY APPLICATION}

What follows is a description of the application of the procedure.

\subsection{Stage 1 - Definition of objective and scope}

In order to identify lower energy use, higher share of renewable energy and lower $\mathrm{CO}_{2}$ emissions, we have analyzed bioethanol supply chain configurations that presented different energy sources and combinations of modes of transport. A ton of bioethanol transported to the port was considered a functional unit.

\subsubsection{Stage 1 - Step 1 - Extension}

The geographic extension covered here considers the supply chain of part of the bioethanol production in the city of Tuverlândia, located in the state of Goiás, which is among the 10 largest producers of bioethanol in Brazil. This choice is due to the geographical position, which favors the use of various modal alternatives. After being produced in this region, bioethanol is transported to the port of São Sebastião, State of Sao Paulo, bound for export.

As temporal extension, it was considered a period of one year. As the technological extension, we considered the technological alternatives available for the transport sector for the next five years.

\subsubsection{Stage 1 - Step 2-Dimension}

Figure 1 shows a part of the life cycle of bioethanol which considers the supply chain. Six alternatives for transfering bioethanol to the port ( $A 1$ to $A 6$ ) were considered including the type of fuel and transport mode used in each of them. It was adopted the premise that bioethanol produced is collected by road mode, and only when transporting it to the port are the other modes used. 

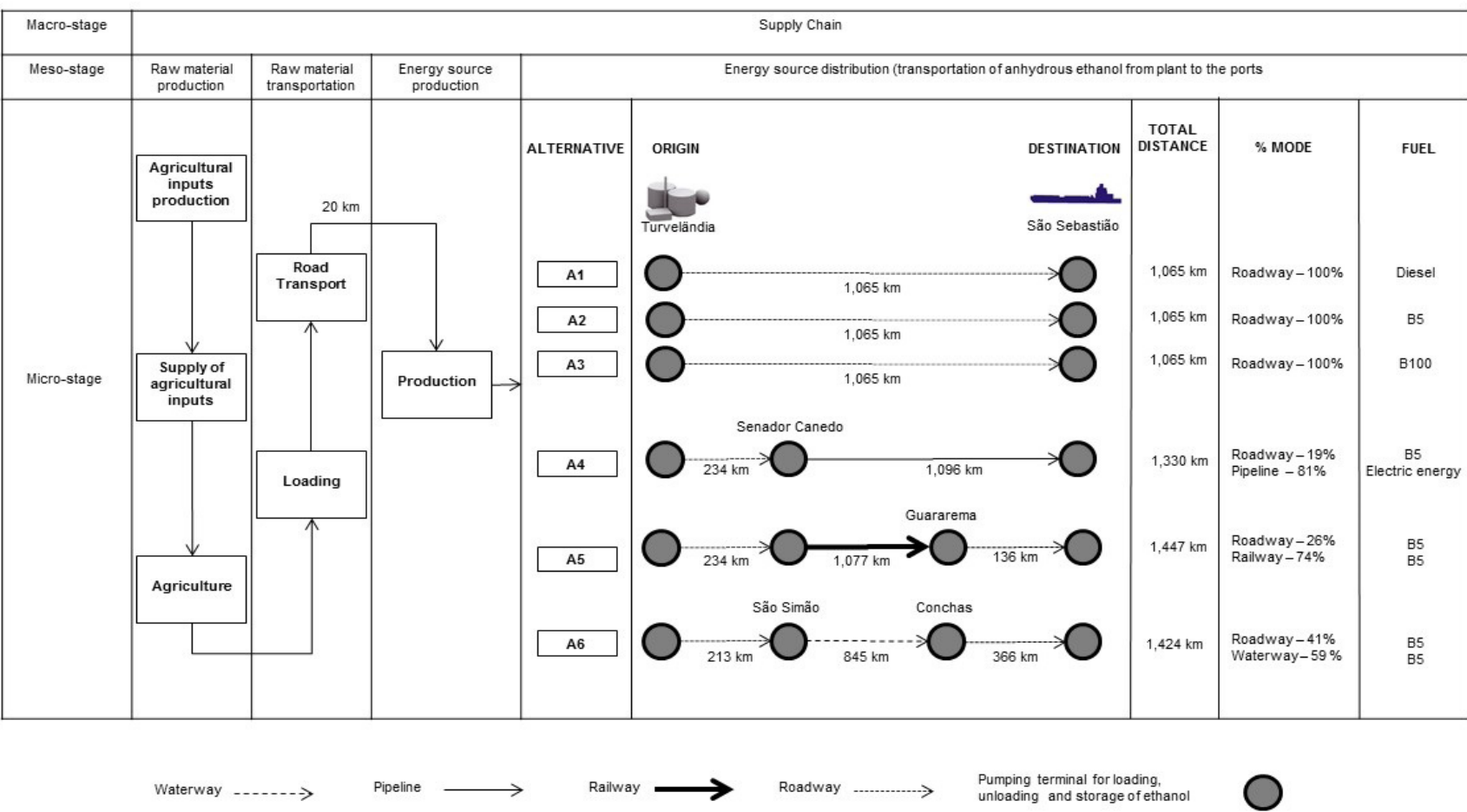

Figure 1. Supply chain of anhydrous ethanol with distribution alternatives and different energy sources for transport

Regarding the production and transport of raw materials and production of energy sources, the same structure is considered for the six alternatives analyzed, varying only the type of energy used, as shown in the last column of Figure 1. Each of these combinations of energy source and alternative transport for transfer to the port was named configuration. In order to facilitate the analysis, the supply chain configurations are named the same way as the ethanol transfer alternatives they present (A1 to A6).

According to Leal Jr. et D'Agosto (2011), some considerations must be made for the scenarios evaluated: (1) the entire rail network has infrastructure for transporting bioethanol; (2) rail transshipments needed due to differences in gauge are not considered; (3) the current terminals and non-existing terminals whose creation is proposed by TRANSPETRO projects designed for the disposal of bioethanol are considered; (4) the volumes being transported justify the use of these modes of transport, and (5) all transport alternatives have installed capacity for the demand.

The analysis also considers: (1) All the energy needed for transhipment / pumping from one mode to another was considered in the calculations; (2) It is assumed that all bioethanol was produced in Turvelândia and transported in tankers truck of 30,000 liters to the port (A1, A2 and $A 3)$ or to a transhipment terminal; (3) It was considered, in average, $20 \mathrm{~km}$ as distance from the sugarcane mills to Tuverlândia;
(4) It was assumed that $25 \%$ of sugarcane is mechanically harvested and the remaining is harvested manually.

\subsection{Stage 2 - Inventory analysis}

The collection of data used in this analysis was conducted based on bibliographic and documentary research, having as main reference D'Agosto et Ribeiro (2009). These authors detail the bioethanol supply chain using diesel in all activities that depend on fossil fuel.

The total amount of energy used together with its share of renewable energy and $\mathrm{CO}_{2}$ emissions are shown for the production of raw material, transport of raw material, production of the energy source and distribution of the energy source. Each of these steps has sub-steps, as shown in Table 1 that refer to the results of the traditional chain scenario (A1). A1 uses diesel as the energy source for transport and uses roadways as the predominant mode for the transport of raw materials and to transfer bioethanol. Maximum, average and minimum values are used due to the variation of data. For the sake of simplicity, the results presented in Table 2 are the average values of meso-stages, calculated based on Table 1, for each alternative scenario.

The data presented in Table 2 were taken into account for elaborating Table 3. It shows the total energy and the percentage of renewable energy contained in each fuel. Leal Jr et D'Agosto (2011) also compare the amount of energy consumed by each transport mode to the roadway, as shown in Table 4. 
Table 1. Total energy consumption, renewable energy and $\mathrm{CO}_{2}$ emission in each meso-stage and micro-stage of the supply chain for $\mathrm{A} 1{ }^{(1)}$

\begin{tabular}{|c|c|c|c|c|c|c|c|c|}
\hline \multicolumn{2}{|c|}{ Energy consumption } & \multicolumn{3}{|c|}{$(\mathrm{MJ} / \mathrm{t})$} & \multicolumn{3}{|c|}{$(\%)$} & \multirow[b]{2}{*}{ Variation } \\
\hline Meso-stages & Micro-stages & Min & Average & Max & Min & Avarage & Max & \\
\hline \multirow{3}{*}{ Production of raw material } & Agriculture & 338.06 & 371.49 & 404.93 & 2.06 & 2.24 & 2.42 & $9.00 \%$ \\
\hline & Supply & 104.38 & 121.35 & 133.57 & 0.64 & 0.73 & 0.8 & $12.03 \%$ \\
\hline & Inputs & 1355.23 & 1355.23 & 1355.23 & 8.25 & 8.17 & 8.09 & $0.00 \%$ \\
\hline \multirow{2}{*}{ Transport of raw material } & Mechanical loading & 83.37 & 91.61 & 99.86 & 0.51 & 0.55 & 0.6 & $9.00 \%$ \\
\hline & Road transport & 450.55 & 474.26 & 497.97 & 2.74 & 2.86 & 2.97 & $5.00 \%$ \\
\hline $\begin{array}{l}\text { Production of the energy } \\
\text { source }\end{array}$ & Ethanol production & 13355.64 & 13355.64 & 13355.64 & 81.35 & 80.56 & 79.71 & $0.00 \%$ \\
\hline \multirow{2}{*}{$\begin{array}{l}\text { Distribution of the energy } \\
\text { source }\end{array}$} & Loading / unloading & 4.39 & 4.67 & 4.95 & 0.03 & 0.03 & 0.03 & $6.00 \%$ \\
\hline & Transport to the port & 726.17 & 804.87 & 902.7 & 4.42 & 4.85 & 5.39 & $10.97 \%$ \\
\hline Total supply chain & & 16417.82 & 16579.17 & 16754.89 & 100 & 100 & 100 & $1.02 \%$ \\
\hline \multicolumn{2}{|c|}{ Renewable Energy } & \multicolumn{3}{|c|}{$(\mathrm{MJ} / \mathrm{t})$} & \multicolumn{3}{|c|}{$(\%)$} & \\
\hline Meso-stages & Micro-stages & Min & Average & Max & Min & Average & Max & Variation \\
\hline \multirow{3}{*}{ Production of raw material } & Agriculture & 0 & 0 & 0 & 0 & 0 & 0 & $0.00 \%$ \\
\hline & Supply & 0 & 0 & 0 & 0 & 0 & 0 & $0.00 \%$ \\
\hline & Inputs & - & - & - & - & - & - & - \\
\hline \multirow{2}{*}{ Transport of raw material } & Mechanical loading & 0 & 0 & 0 & 0 & 0 & 0 & $0.00 \%$ \\
\hline & Road transport & 0 & 0 & 0 & 0 & 0 & 0 & $0.00 \%$ \\
\hline $\begin{array}{c}\text { Production of the energy } \\
\text { source }\end{array}$ & Ethanol production & 13355.64 & 13355.64 & 13355.64 & 99.97 & 99.97 & 99.96 & $0.00 \%$ \\
\hline \multirow{2}{*}{$\begin{array}{l}\text { Distribution of the energy } \\
\text { source }\end{array}$} & Loading / unloading & 4.39 & 4.67 & 4.95 & 0.03 & 0.03 & 0.04 & $6.00 \%$ \\
\hline & Transport to the port & 0 & 0 & 0 & 0 & 0 & 0 & $0.00 \%$ \\
\hline Total supply chain & & 13360.04 & 13360.32 & 13360.6 & 100 & 100 & 100 & $0.00 \%$ \\
\hline \multicolumn{2}{|c|}{ CO2 Emission } & \multicolumn{3}{|c|}{$(\mathrm{kg} / \mathrm{t})$} & \multicolumn{3}{|c|}{$(\%)$} & \\
\hline Meso-stages & Micro-stages & Min & Average & Max & Min & Average & Max & Variation \\
\hline \multirow{3}{*}{ Production of raw material } & Agriculture & 23.54 & 25.87 & 28.2 & 19.86 & 19.93 & 19.86 & $9.01 \%$ \\
\hline & Supply & 7.27 & 8.45 & 9.3 & 6.13 & 6.51 & 6.55 & $12.01 \%$ \\
\hline & Inputs & - & - & - & - & - & - & - \\
\hline \multirow{2}{*}{ Transport of raw material } & Mechanical loading & 5.8 & 6.38 & 6.95 & 4.9 & 4.92 & 4.9 & $9.01 \%$ \\
\hline & Road transport & 31.38 & 33.03 & 34.68 & 26.46 & 25.45 & 24.42 & $5.00 \%$ \\
\hline $\begin{array}{l}\text { Production of the energy } \\
\text { source }\end{array}$ & Ethanol production & 0 & 0 & 0 & 0 & 0 & 0 & $0.00 \%$ \\
\hline \multirow{2}{*}{$\begin{array}{c}\text { Distribution of the energy } \\
\text { source }\end{array}$} & Loading / unloading & 0 & 0 & 0 & 0 & 0 & 0 & $0.00 \%$ \\
\hline & Transport to the port & 50.58 & 56.06 & 62.88 & 42.65 & 43.19 & 44.27 & $10.97 \%$ \\
\hline Total supply chain & & 118.6 & 129.82 & 142.04 & 100 & 100 & 100 & $9.03 \%$ \\
\hline
\end{tabular}

Note: “_” it's not applied, (1) Scenario A1 uses diesel in all activities that depend on fossil fuel. 


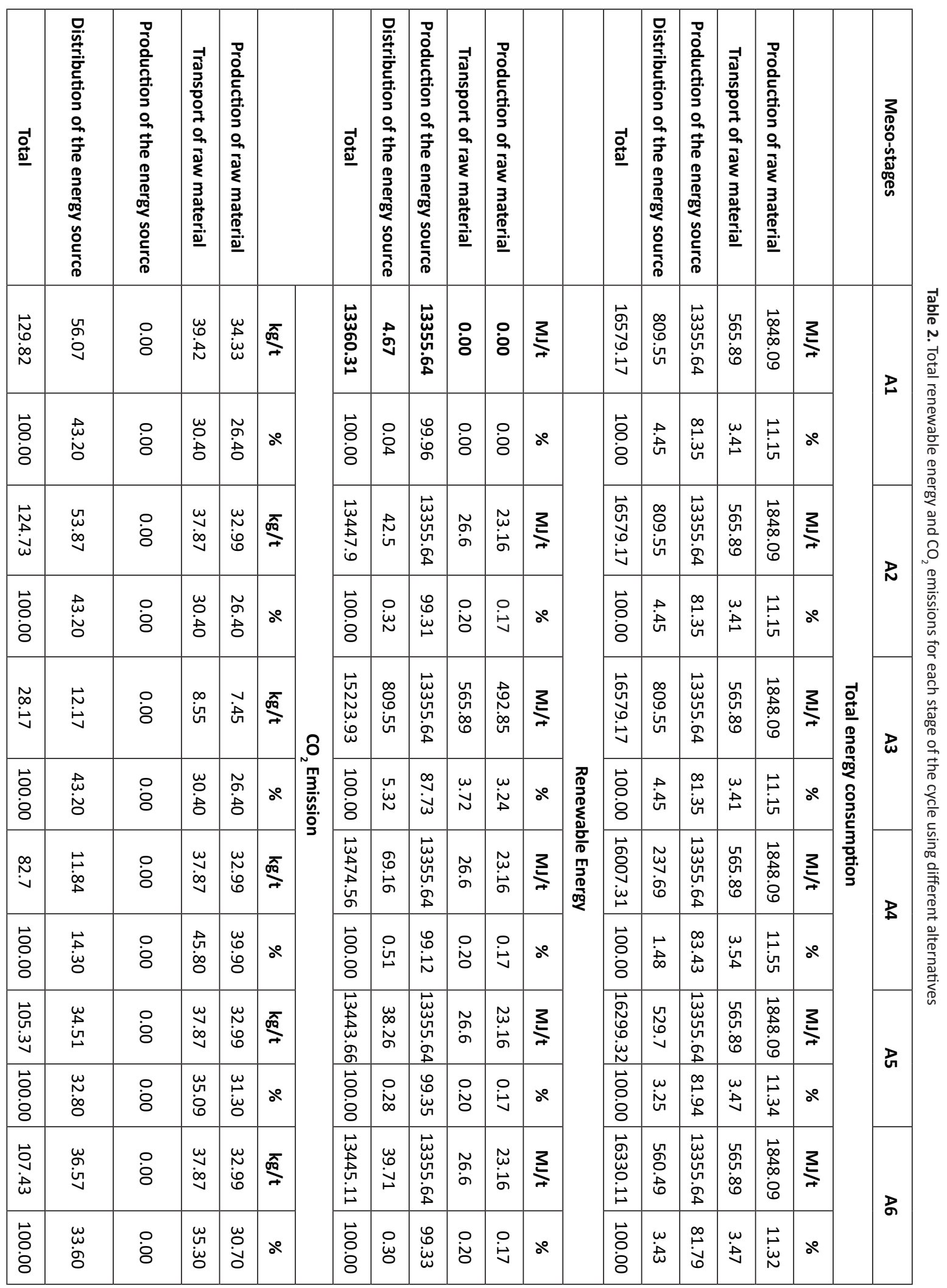


Table 3. Total energy and share of renewable energy for diesel, B5 and B100

\begin{tabular}{|l|c|c|}
\hline & $\begin{array}{c}\text { Energy per liter of } \\
\text { fuel (MJ) }\end{array}$ & $\begin{array}{c}\text { Renewable energy } \\
\text { (\%) }\end{array}$ \\
\hline Diesel & 38.32 & 0.00 \\
\hline B5 & 38.19 & 4.70 \\
\hline B100 & 35.70 & 100.00 \\
\hline \multicolumn{2}{|c|}{ Source: Leal Jr and D'Agosto (2011) }
\end{tabular}

Table 4. Percentage relation of the energy consumed in each mode of transport compared to road mode

\begin{tabular}{|l|c|}
\hline \multicolumn{1}{|c|}{ Mode } & $\begin{array}{c}\text { Energy consumed compared } \\
\text { to road mode (\%) }\end{array}$ \\
\hline Pipeline & 6.70 \\
\hline Railway & 29.00 \\
\hline Waterways & 17.05 \\
\hline
\end{tabular}

Source: Leal Jr and D’Agosto (2011)

In the case of $\mathrm{CO}_{2}$, the emissions are proportional to the type of energy used. Therefore, it was considered in each configuration both the percentage of renewable energy used and the fuel savings, for modes other than the road mode.

Figures 2, 3 and 4 show, respectively, the amount of total energy consumption, renewable energy use and $\mathrm{CO}_{2}$ emissions, in absolute values. Figure 2 shows that, concerning the total energy consumed, all alternatives present practically the same consumption (around 16,000 $\mathrm{MJ} / \mathrm{t}$ ). The best alternative (A4) is only $3 \%$ lower than $\mathrm{A} 1, \mathrm{~A} 2$ and $\mathrm{A} 3$ (the worse ones). It means that using pipelines to distribution made nearly no difference.

In Figure 3, it can be noted that $\mathrm{A} 3$ became the best alternative: it is $12 \%$ larger than $\mathrm{A} 1$ (the worst alternative) in relation to the amount renewable energy consumed. So, the use of B100 in road mode, in this case, is better than changing the mode of transport.

As for total $\mathrm{CO}_{2}$ emissions, demonstrated in Figure 4, it is clear that $A 3$ is far superior if compared to the other alternatives ( $A 3$ is 4.6 and 3.3 times smaller than $A 1$ and $A 4$, respectively).

Considering that mid-stages of raw material production and energy source production have very high values if compared to the others, it is important to evaluate the transport mid-stage apart. Doing so, we can analyze the improvements resulting from the use of renewable fuels or from the alternatives to the road mode.

So, Figures 5, 6 and 7 present the results considering only the transport (meso-stages on the transport of raw materials and distribution of the energy source). Analyzing Figure 5, we can notice that the amount of energy consumed varies among the alternatives. A4 keeps being the best choice, but now it consumes 3.4 times less than $\mathrm{A} 1, \mathrm{~A} 2$ and $\mathrm{A} 3$. Besides, alternatives $A 5$ and $A 6$ also get better results. It shows that alternatives modes of transport can bring improvements to this mid-stage, since they are more energy efficient than road transport.

Regarding to renewable energy, the difference between A3 and the other alternatives became even more considerable. A3 is $100 \%$ renewable while the second best alternative (A4) is just $29.10 \%$. It confirms that use of B100 in road mode, in this case, is better than alternatives the mode of transport.

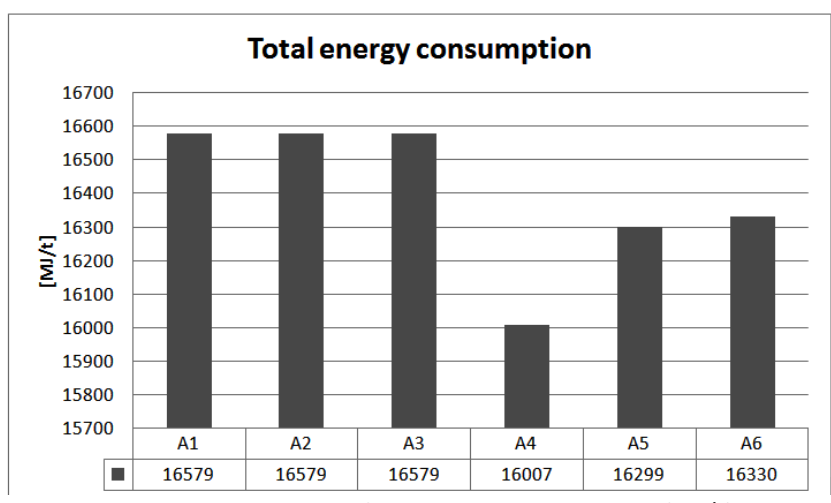

Figure 2. Total energy for the entire supply chain (MJ/t)

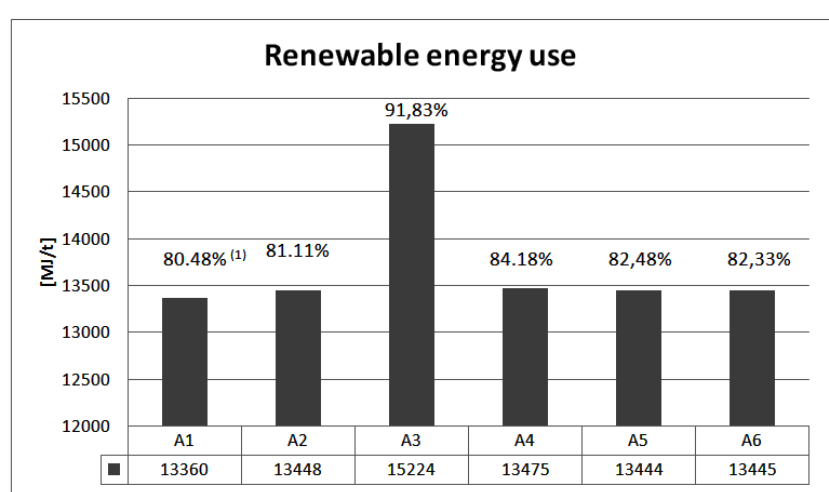

Note: (1) Percentage of renewable energy for each alternative related to the total energy consumed

Figure 3. Renewable energy for the entire supply chain (MJ/t)

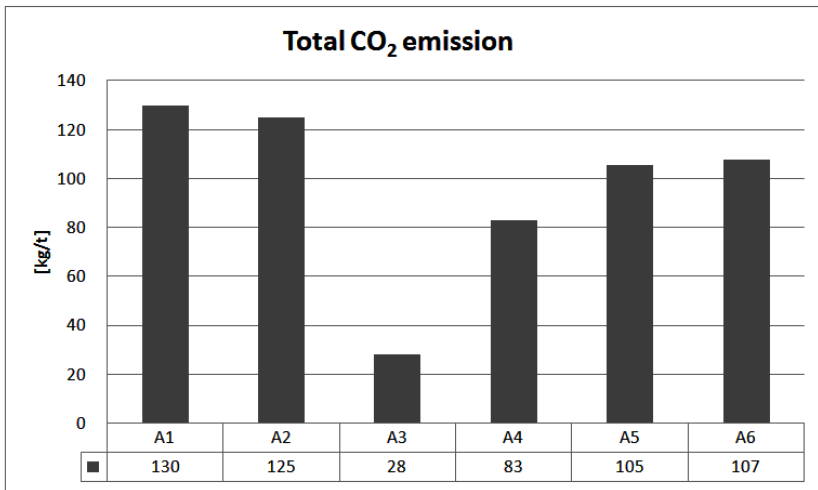

Figure 4. $\mathrm{CO}_{2}$ emission for the entire supply chain $(\mathrm{kg} / \mathrm{t})$ 
Brazilian Journal of Operations \& Production Management

Volume 13, Número 2, 2016, pp. 138-148 DOI: 10.14488/BJOPM.2016.v13.n2.a1

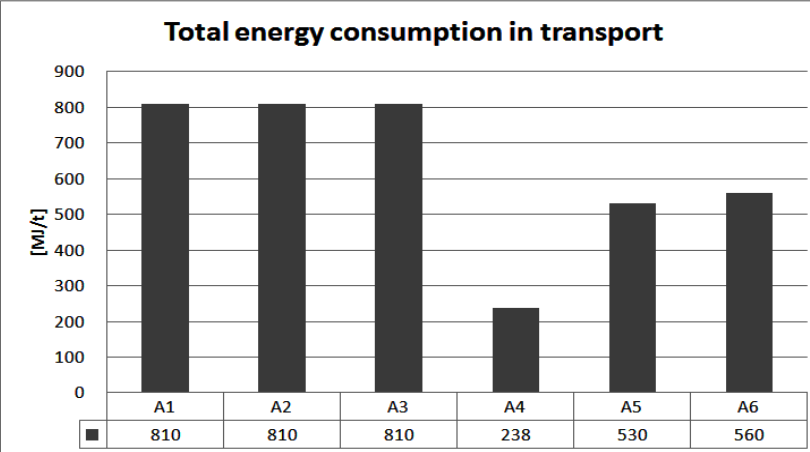

Figure 5. Total energy consumed in transport (MJ/t)

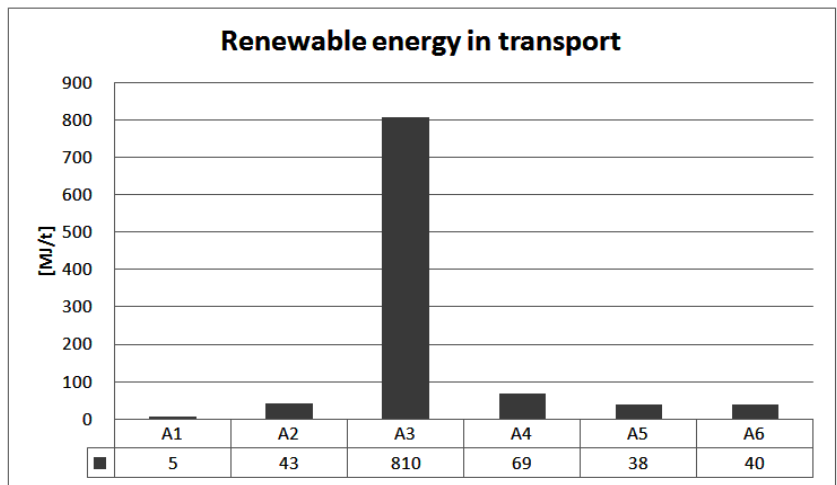

Note: (2) Proportion of renewable energy consumed in transport in each alternative

Figure 6. Renewable energy consumed in transport (MJ/t)

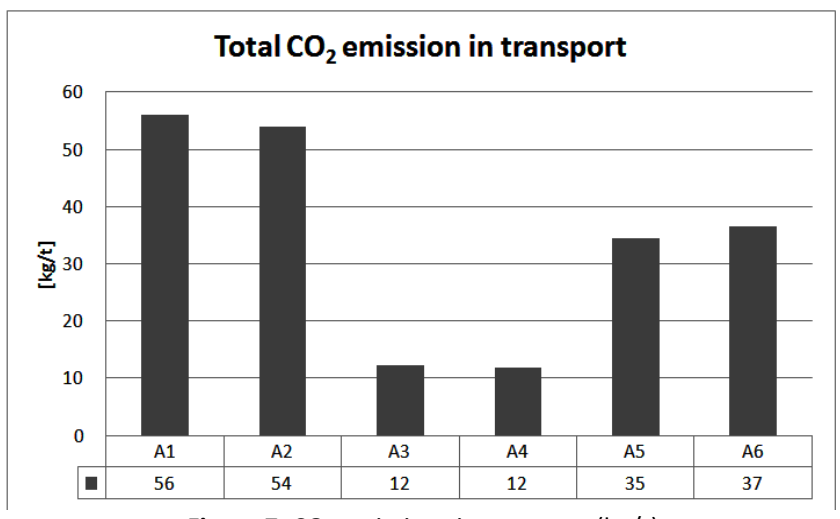

Figure 7. $\mathrm{CO}_{2}$ emissions in transport $(\mathrm{kg} / \mathrm{t})$

Considering just transport, $\mathrm{A} 3$ is not far better than the other alternatives anymore. A4 emits just $9 \%$ more $\mathrm{CO}_{2}$ that $\mathrm{A} 3$ and is the alternative which has the less consumption of energy (as shown in figure 5). So, A3 and A4 can be considered both important alternatives to bioethanol supply chain.

\subsection{Stage 3 - Data evaluation}

The data evaluation on energy efficiency, renewable energy and $\mathrm{CO}_{2}$ emission was performed by means of comparing data in tables 1 and 2 in order to verify their coherence and consistency.
The objective of this stage is guiding a possible reevaluation of the data, identifying critical flows. Based on Maurice (2000) it was considered that all the flows with weight greater than $10 \%$ and variation between minimum and maximum greater than $5 \%$ are critical. Analyzing Table 1 , we can notice that five micro-stages have a weight greater than $10 \%$ of total emission or energy consumption (total or renewable). Among these, just the ones related to $\mathrm{CO}_{2}$ emission have a variation greater than $5 \%$. This happens due to the variations of emission factors considered, which were established based on the theoretical framework. However, none of them involves data from general use so, the results were not influenced by the variation.

Factors such as availability of data, resources and time limited the scope of this study. This model seeks to address major and indispensable elements for a proper understanding of the real physical system. It is important to remember that data validation is linked to the treatment given to the unavailable data. Its deletion or substitution for data that were calculated or obtained by analogy is justified within the work. The existence of estimated data is better than its exclusion.

The data used for the calculations shown in the previous tables and charts were extracted from D'Agosto et Ribeiro (2009), which may cause slight discrepancies in the results since they are secondary data. Besides the data of total energy, renewable energy and $\mathrm{CO}_{2}$ emissions for all six scenarios were based on average values found in the literature. Another observation concerns the updating of data, since many production and transport technologies are constantly evolving, which may bring small differences in actual results.

\subsection{Stage 4 - Analysis of the results}

In a bioethanol supply chain, most of the energy is used in the production of the energy source, ranging from a minimum of $81.35 \%$ in $A 1, A 2$ and $A 3$ (in which transport to the port is done by roadway) to a maximum of $83.43 \%$ for A4 (which uses pipeline in most of the product's transport). Considering the transport of the energy source, the minimum energy percentage of $1.48 \%$ occurred in $A 4$ and the maximum of $4.45 \%$ for $A 1, A 2$ and $A 3$.

For the production of raw materials, A1 has no share of renewable energy as it uses pure diesel. The largest share of renewable energy is of $3.24 \%$ for A3, which uses B100. Similar to the above, the transport of raw material has no share of renewable energy for $\mathrm{A} 1$ and $\mathrm{A} 3$ reached the largest percentage $(3.72 \%)$.

The production of the energy source has the largest share of renewable energy for all alternatives, with a minimum of $87.73 \%$ for A3 and maximum of $99.96 \%$ for A1. Regarding the distribution of the energy source, the lowest percentage 
of renewable energy lies in $\mathrm{A} 1$ with $0.04 \%$ and the highest in $\mathrm{A} 3$ with $5.32 \%$.

The production of raw material has a lower percentage of $\mathrm{CO}_{2}$ emission for $\mathrm{A} 1, \mathrm{~A} 2$ and $\mathrm{A} 3$ : each alternative emits $26.40 \%$ of the total amount. The highest percentage of $\mathrm{CO}_{2}$ emission, in this step, occurs in A4 (39.9\%). In the case of transport of raw materials, the highest percentage of $\mathrm{CO}_{2}$ is seen in alternative $A 4$ and the lowest in $A 1, A 2$ and $A 3$, which are equal.

During the production of the energy source there is no emission of $\mathrm{CO}_{2}$ in all of the alternatives. For the distribution of the energy source, the lowest share of $\mathrm{CO}_{2}$ emissions is shown by $A 4$, which uses pipelines, with $14.30 \%$ of the total. The largest share is shown by A1, A2 and A3 with $43.20 \%$, each one.

To complement the analysis, table 5 was created so as to compare the results of all scenarios to $A 1$, which was the original developed configuration.

Table 5. Comparison of improving the amount of consumed energy, renewable energy and $\mathrm{CO}_{2}$ emissions of other configurations relative to A1 (\%)

\begin{tabular}{|c|c|c|c|c|c|}
\hline $\begin{array}{c}\text { Analyzed } \\
\text { factors }\end{array}$ & A2 & A3 & A4 & A5 & A6 \\
\hline $\begin{array}{c}\text { Consumed } \\
\text { energy }\end{array}$ & 0.00 & 0.00 & 3.57 & 1.72 & 1.53 \\
\hline $\begin{array}{c}\text { Renewable } \\
\text { energy }\end{array}$ & 0.66 & 13.95 & 0.86 & 0.62 & 0.63 \\
\hline $\begin{array}{c}\mathbf{C O}_{2} \\
\text { emissions }\end{array}$ & 4.08 & 360.84 & 56.98 & 23.20 & 20.84 \\
\hline
\end{tabular}

In relation to total energy consumption, A4 showed an improvement of $3.57 \%$ compared to $A 1$. This is due to the considerable improvement in energy consumption that occurs in the transport of the energy source, which is made by pipeline. In the other stages of the cycle there is no improvement in terms of energy use. It is valid to highlight that the improvement of $1.72 \%$ for $\mathrm{A} 5$ in relation to $A 1$ and of $1.53 \%$ for $A 6$ compared to $A 1$ is also due to an improvement in energy use and in energy source transport. Improving efficiency, in the case of total energy, means the least possible use of energy.

Regarding the proportion of renewable energy consumed, the improvement of $13.95 \%$ in A3 compared to alternative $A 1$ is due to the use of B100, which leads to the use of a considerable portion of renewable energy in the production and transport of raw material stages, which did not take place in $\mathrm{A} 1$.

In the case of transport of energy source, the percentage of renewable energy was very small in $A 1$, significantly increasing in A3. There is also a large increase in A4 that uses pipeline to transfer bioethanol. This improvement, however, was not reflected in the total performance, with A4 being only $0.86 \%$ more efficient than A1. It happens because B5 is the fuel used in the road transport of raw materials and transport of energy source. It is worth mentioning that greater efficiency, in the case of renewable energy, indicates a larger share of renewable energy used in the cycle.

In the case of $\mathrm{CO}_{2}$ emission, alternative $\mathrm{A} 3$ proved to be the most efficient, with an improvement of $360.84 \%$ compared to A1. This is due to the use of B100 as fuel throughout the road transport, which brings improvements concerning $\mathrm{CO}_{2}$ emissions for all stages of the production cycle except the energy source production, which already uses electricity. A4 also showed significant improvement, compared to A1, being $56.98 \%$ more efficient in terms of $\mathrm{CO}_{2}$ emissions. This is due to the use of pipelines in part of the transport of the energy source. It is also worth mentioning that greater efficiency in the case of $\mathrm{CO}_{2}$ emission indicates a smaller amount of the gas being emitted into the atmosphere.

Considering only the transport of the bioethanol compared to the total energy consumption, A4 is the best configuration because it has lower energy consumption. This is due to the use of pipelines in most of its path. Regarding the share of renewable energy, the best configuration is $A 3$, mainly due to the use of B100, with $5.32 \%$ of the total use of renewable energy. The second best configuration would be A4, with a significant difference from the best one, presenting only $0.51 \%$ of the total use of renewable energy. Regarding $\mathrm{CO}_{2}$ emissions, the best alternative is $\mathrm{A} 4$, with relatively little difference when compared to $\mathrm{A} 3$.

When analyzing the bioethanol supply chain, in relation to the total energy, the best setting is $A 4$, which has the highest energy efficiency, followed by $\mathrm{A} 3$. Regarding the percentage of renewable energy, the best configuration is A3. As for $\mathrm{CO}_{2}$ emissions, the best configuration is also $\mathrm{A} 3$, followed by $A 4$, with considerable difference between them.

It was concluded that it would be better to keep using the roads to transport the energy source, changing the use of diesel B5 (now mandatory in Brazil) for pure biodiesel (B100) in the whole chain of bioethanol (A3 scenario). Alternative A4 (road-pipeline transport) should also be considered as it is capable of reducing the total energy, increase renewable energy and reduce $\mathrm{CO}_{2}$ emissions.

\section{CONCLUSIONS}

This paper aimed to present a study of configurations of bioethanol supply chains, using different modal alternatives and renewable energy sources. It was possible to identify which one of these settings is the most appropriate in terms of lower total energy consumption, higher usage renewable 
energy and lower $\mathrm{CO}_{2}$ emissions, reaching the proposed objective.

We have identified that the most appropriate setting is not the one that consumes less energy (A4), but the one that uses more renewable energy (A3). Additionally, this is also the alternative that requires less modification on the existing infrastructure to transfer bioethanol to the port. Besides, A3 is less impacted by the seasonality related to the production of this biofuel (A4 uses pipelines which are influenced by seasonality).

As a limitation of this study, other impacts resulting from the implementation of the two best alternatives were not evaluated. In the case of A3, it would be important to find which investments are necessary to provide a greater amount of biodiesel that could be used in transport sector. About A4, it would also be important to research about the infrastructure investment that would be necessary for transport bioethanol by pipelines. For this last alternative, it is noteworthy that a demand study would be recommended, since the production and transport of bioethanol are limited to seasonal plantings of sugarcane, which could derail the investment.

Another limitation that may be considered is the scarce availability of data related to the supply chain of bioethanol in Brazil and the limited access to specialized materials on bioethanol data. Given these limitations, it is recommended that studies be made on the feasibility of the implementation of alternatives with better performance, the creation and analysis of alternatives that might be even more efficient (such as using the B100 blend and electric energy allied to other alternatives of transport). As an example, it is suggested the use of electricity in the production of raw materials and production of energy source, using B100 on road transport of raw materials and pipelines to transport the energy source.

\section{ACKNOWLEDGEMENTS}

We thank CNPq (Process 308729/2014-5 Research Productivity Fellowship Holder-CNPq Brazil) for financial support.

\section{REFERENCES}

[ANFAVEA] National Association of Automobile Manufacturers. (2012). Yearbook 2012. http://www.anfavea. com.br/anuario.html. Access: 19th December, 2013.

Armstrong, A.P., Akhurst, M.A. (2000). Alternative fuels: well-to-wheels energy use e $\mathrm{CO}_{2}$ comparisons. London (United Kingdom): BP Amoco Search Group.

Ballou, R.H. (2004). Supply Chain Management: Business Logistics. Bookman: São Paulo.
Beer, T.; Grant, T.; Morgan, G.; Lapszewicz, J.; Anyon, P.; Edwards J. (2001). Comparison of Transport Fuels: Life Cycle Emissions Analysis of Alternative Fuels for Heavy Vehicles. (Australia): Australian Greenhouse Office.

[BNDES] National Development Bank. (2007). Support of BNDES to the biofuels sector - $2007<$ http://www.bndes. gov.br/SiteBNDES/export/sites/default/bndes_pt/Galerias/ Arquivos/empresa/download/apresentacoes/mariante_ biocombustiveis.pdf. Access: 20th August, 2012.

Bouwman, E.M.; Moll, H.C. (2002). Environmental analyses of land transportation systems in The Netherlands. Transportation Research Part D: Transport and Environment, Vol. 7, No. 5, pp. 331-345.

[Brasil]. Brazil Federal Government. (2012). Biofuels 2012. http://www.brasil.gov.br/sobre/economia/energia/ matriz-energetica/biocombustiveis. Access: 25th May, 2012.

Brazilian Association of Technical Standards. (2001). NBR ISO 14040 - Environmental Management: life cycle assessment: principles and structure. Rio de Janeiro (Brazil): Brazilian Association of Technical Standards.

Burgess, S.C.; Choi, J.M.J. (2003). A parametric study of the energy demands of car transportation: a case study of two competing commuter routes in the UK. Transportation Research Part D: Transport and Environment. Vol. 8, No. 1, pp. 21-36.

Chang, B.; Kendall, A., (2011). Life cycle greenhouse gas assessment of infrastructure construction for California's high-speed rail system. Transportation Research Part D: Transport and Environment. Vol. 16, No. 6, pp. 429-434.

Collela, W.G.; Jacobson, M.G.; Golden, D.M. 2005. Switching to a U.S. hydrogen fuel cell vehicle fleet: the resultant change in emissions, energy use, and greenhouse gases. Journal of Power Sources, Vol. 150, No. 1, pp.150-181.

D’Agosto, M.A.; Ribeiro, S.K. (2009). Assessing total and renewable energy in Brazilian automotive fuels. A life cycle inventory ( $\mathrm{LCl}$ ) approach. Renewable and Sustainable Energy Reviews, Vol. 13, No.6, pp. 1326-1337.

Dantas Filho, P.L.; Franco, E.G.; Taioli, F. (2008). The logistics of ethanol for fuel cell cars in Brazil and the United States. Paper presented at: XI Symposium of production management, logistics and international operations; São Paulo. Brazil.

Demir, E.; Bektas, T.; Laporte, G.A. (2011). Comparative analysis of several vehicle emission models for road freight transportation. Transportation Research Part D: Transport and Environment, Vol. 16, No. 5, pp. 347-357.

Foley, J.; Hass, D.; Hartley, K.; Lant, P. (2010). Comprehensive life cycle inventories of alternative wastewater treatment systems. Water Research, Vol. 44, No. 5, pp. 1654-1666. 
Furuholt, E. (1995). Life cycle assessment of gasoline and diesel. Resources, Conservation and Recycling, Vol. 14, No. 3, pp. 251-263.

Ha, H.; Yoshida, Y.; Zhang, A. (2011). Social efficiency benchmarking of Japanese domestic transport services: A comparison of rail and air. Transportation Research Part D: Transport and Environment, Vol. 16, No.7, pp. 554-561.

Hackney, J.; Neufville, R. (2001). Life cycle of alternative fuel vehicles: emissions, energy and cost trade-offs. Transportation Research Part A, Vol. 35, No. 3, pp. 243-66.

$\mathrm{Hu}$, Z.; Pu, G.; Fang, F.; Wang C. (2004). Economics, environment, and energy life cycle assessment of automobiles fueled by bio-ethanol blends in China. Renewable Energy, Vol. 29, No. 14, pp. 2183-2192.

[IEA] International Energy Agency. (1999). Automotive Fuels for the Future. The Search for Alternative. Paris (France) Office of Energy Efficiency Technology and R\&D.

Kadam, K.L. (2002). Environmental benefits on a life cycle basis of using bagasse derived ethanol as a gasoline oxygenate in India. Energy Policy, Vol. 30, No. 5, pp. 371384.

Kim G, Kim K, Lee D, Han C, Kim H, Jun J. (2010). Development of a life cycle cost estimate system for structures of light rail transit infrastructure. Automation in Construction. 19(3), 308-325.

Kreith, F.; West, R.E.; Isler, B.E. (2002). Legislative and technical perspective for advanced ground transportation systems. Transportation Quarterly, Vol. 56, No. 1, pp. 51-73.

Leal Jr, I.C.; D’Agosto, M.A. (2011). Modal choice for transportation of hazardous materials: the case of land modes of transport of bio-ethanol in Brazil. Journal of Cleaner Production, Vol. 19, No. 2, pp. 229-240.

Lechón, Y.; Cabal, H.; de la Rua, C.; Caldés, N.; Santamaría, M.; Sáez R. (2009). Energy and greenhouse gas emission savings of biofuels in Spain's transport fuel. The adoption of the EU policy on biofuels. Biomass and Bioenergy, Vol. 33, No. 6, pp. 920-932.

Lee, C.; Kim, Y.; Pruitichaiwiboon, P.; Kim, J.; Lee, K.; Ju, C. (2010). Assessing environmentally friendly recycling methods for composite bodies of railway rolling stock using life-cycle analysis. Transportation Research Part D: Transport and Environment, Vol. 15, No. 4, pp. 197-203.

Maurice, B.; Frischknecht, R.; Coelho-Schwirtz, V.; Hungerbuhler, K.; (2000). Uncertainty analysis in the life cycle inventory. Application to the production of electricity with French coal power plants. Journal of Cleaner Production. Vol. 8, No.2, pp. 95-108.

Mendonça, J.F.; Leal Junior, I.C. Comparison of production and logisitics costs of etanol in Brazil and the United States.
Paper presented at: Symposium for Excellence in Technology and Management - VII SEGET; Resende, Brazil.

Neupane, B.; Halog, A.; Dhungel, S. (2011). Attributional life cycle assessment of woodchips for bioethanol production. Journal of Cleaner Production, Vol. 19, No. 6, pp. 733-741.

O’Donnell, B.; Goodchild, A.; Cooper, J.; Ozawa, T. (2009). The relative contribution of transportation to supply chain greenhouse gas emissions: A case study of American wheat. Transportation Research Part D: Transport and Environment, Vol. 14, No. 7, pp. 487-492.

Ou, X.; Yan, X.; Zhang, X.; Liu, Z. (2012). Life-cycle analysis on energy consumption and GHG emission intensities of alternative vehicle fuels in China. Applied Energy, Vol. 90, No. 1, pp. 218-224.

Poeschl, M.; Ward, S.; Owende, P. (2012). Environmental impacts of biogas deployment - Part I: life cycle inventory for evaluation of production process emissions to air. Journal of Cleaner Production, Vol. 24, No. 1, pp. 168-183.

Pootakham, T.; Kumar A. (2010). A comparison of pipeline versus truck transport of bio-oil. Bioresource Technology, Vol. 101, No. 1, pp. 414-421.

Sheehan, J.; Camobreco, V.; Duffiled, J.; Graboski, M.; Shapouri, H. (1998). Life Cycle Inventory of Biodiesel and Petroleum Diesel for Use in an Urban Bus. Colorado (USA): National Renewable Energy Laboratory.

[UNICA] Union of Producers of Sugarcane. (2011). Statistical Release. www.unica.com.br/dadoscotacao/ estatistica/. Access: 7th July, 2012

Vihermaa, L.; Lettenmeier, M.; Saari, A. (2006). Natural resource consumption in rail transport: $A$ note analyzing two Finnish railway lines. Transportation Research Part D: Transport and Environment. Vol. 11, No. 3, pp. 227-232.

Wang, C.; Zhou, S.; Hong, X.; Qiu, T.; Wang, S. (2005). A comprehensive comparison of fuel options for fuel cell vehicles in China. Fuel Processing Technology, Vol. 86, No. 7, pp. 831-845.

Wang, M.; Saricks, C.; Wu, M. (1997). Fuel-cycle fossil energy use and greenhouse gas emissions of fuel ethanol produced from U.S. midwest corn. Illinois (USA): Centre of Transportation Research, Argone Laborator. 